\title{
ENVIRONMENTAL CITIZEN DEMANDS: THE MANIFESTOS FOR THE AGRICULTURE PROTECTION IN THE METROPOLITAN REGION OF BARCELONA AND THE DEVELOPMENT OF THE NEW ENVIRONMENTAL CULTURE.
}

\author{
Maria Àngels Alió ${ }^{1}$ \\ Marc Casanovas ${ }^{2}$ \\ Davide Giachino ${ }^{3}$
}

\begin{abstract}
The relationship between city and country is an old, recurring topic. In this article, we analyse this relation by examining a set of manifestos drawn up in Catalonia between 1976 and 2013, calling for environmental protection, with a particular regard to agriculture. On the basis of these documents, we reflect on the critical state of agriculture in contemporary urban societies and on the development of new environmental cultures. The article introduces manifestos as documents that can be used to analyse a population's interpretations of contemporary problems, in addition to social and environmental processes, and examines the place of these manifestos in, and their relationship with Catalonia's urban systems. Our analysis of these manifestos highlights the cultural shift that is currently occurring in many Western urban societies in relation to the environment, agriculture and food.
\end{abstract}

Keywords: ecologist movement, citizen demands, agroecology, manifestos, environmental cultures.

\section{DEMANDAS AMBIENTAIS URBANAS: MANIFESTOS PARA A PROTECÇÃO AGRÍCOLA NA REGIÃO METROPOLITANA DE BARCELONA E O DESENVOLVIMENTO DA NOVA CULTURA AMBIENTAL.}

\section{Resumo}

A relação entre cidade e país é um tópico antigo e recorrente. Neste artigo, analisamos essa relação examinando um conjunto de manifestos elaborados na Catalunha entre 1976 e 2013, apelando à proteção ambiental, com especial atenção à agricultura. Com base nesses documentos, refletimos sobre o estado crítico da agricultura nas sociedades urbanas contemporâneas e sobre o desenvolvimento de novas culturas ambientais. O artigo apresenta os manifestos como documentos que podem ser usados para analisar as interpretações de uma população de problemas contemporâneos, além de processos sociais e ambientais, e examina o lugar desses manifestos e sua relação com os sistemas urbanos da Catalunha. Nossa análise desses manifestos destaca a mudança cultural que está ocorrendo atualmente em muitas sociedades urbanas ocidentais em relação ao meio ambiente, agricultura e alimentos.

Palavras-chaves: movimento ecologista, demandas cidadãs, agroecologia, manifestos culturas e ambientais.

\footnotetext{
${ }^{1}$ University of Barcelona. E-mail: alio@ub.edu.

${ }^{2}$ Universitat de Barcelona.

${ }^{3}$ Fondazione Giovanni Goria e Fondazione CRT.
} 


\section{DEMANDAS CIUDADANAS AMBIENTALES: LOS MANIFESTOS PARA LA PROTECCIÓN AGRÍCOLA EN LA REGIÓN METROPOLITANA DE BARCELONA Y EL DESARROLLO DE LA NUEVA CULTURA AMBIENTAL.}

\section{Resumen}

La relación entre ciudad y país es un tema recurrente y antiguo. En este artículo analizamos esta relación mediante el examen de un conjunto de manifiestos elaborados en Cataluña entre 1976 y 2013, que reclaman la protección del medio ambiente, con especial atención a la agricultura. Sobre la base de estos documentos, reflexionamos sobre el estado crítico de la agricultura en las sociedades urbanas contemporáneas y sobre el desarrollo de nuevas culturas ambientales. El artículo presenta los manifiestos como documentos que pueden usarse para analizar las interpretaciones de una población de los problemas contemporáneos, además de los procesos sociales y ambientales, y examina el lugar de estos manifiestos y su relación con los sistemas urbanos de Cataluña. Nuestro análisis de estos manifiestos pone de relieve el cambio cultural que está ocurriendo actualmente en muchas sociedades urbanas occidentales en relación con el medio ambiente, la agricultura y la alimentación.

Palabras claves: movimiento ecologista, demandas ciudadanas, agroecología, manifiestos culturas y ambientales.

\section{INTRODUCTION}

The relationship between city and country is an old, recurring topic; however, a number of new approaches that focus on emerging objectives and the new social actors associated with agricultural and urban environments have recently been developed. In this article, we examine this relationship using a set of manifestos drawn up in Catalonia between 1976 and 2013, calling for environmental protection, with a particular regard to agriculture ${ }^{4}$. On the basis of these documents, we reflect on the critical state of agriculture in contemporary urban societies and argue that the city of Barcelona and its metropolitan system play a main role in structuring the territory that determines many of its agricultural demands.

This article is divided into five parts. The first introduces manifestos as documents that permit in-depth analyse the emerging interpretations of contemporary problems and social and environmental processes. The second examines the cultural shift that is currently occurring in

\footnotetext{
${ }^{4}$ Participants in the research included Gerard Jori, untiring collaborator in the 2GES group until 2014, and Santiago Riutor, a research grantholder in 2010. We are particularly grateful to Vicenç Casals, Mercè Tatjer and Eduard Tudela for their constant support and advice. After 2011, participants included Hosana Raquel Mederiros Garcia, Apuc Hernández, Clara Sanchez and Jennifer Thiers.

All of the manifestos are available from an online database containing 136 manifestos at the Centre for Social Ecology Resources (www.ub.edu/cres).
} 
Western urban societies and the role of agriculture and food in territories that are becoming increasingly urban. The third presents the results of the analysis of these manifestos in Catalonia, specifically those relating to agriculture. The fourth analyses the place of the manifestos in the territory and their relationship with Catalan urban systems, including a discussion of the legal system that provides environmental protection. Finally, we conclude by reflecting on recent developments within the new environmental culture that characterises urban societies and the extremely important role that agriculture and food play in them.

\section{MANIFESTOS FOR ENVIRONMENTAL PROTECTION: AN EXPRESSION OF CONTEMPORARY ENVIRONMENTAL CULTURE}

Manifestos are documents written to make public a demand about a fact or situation which their authors consider negative and hope to change. Some, including the well-known Communist Manifesto, are markedly political; others stress aspects that might be related, for example, to culture, the economy, labour or the environment.

There is almost unanimous agreement that the Western history of manifestos on environmental protection began with Aldo Leopold (1949) when he coined the expression "Land Ethics" in the conclusions to one of his books. This relatively brief text was to mark a before and an after in approaches to the whys and wherefores of the changes that should be introduced in relations between society and nature and, more specifically, in those between economy and culture. Since the mid-sixties, environmental manifestos have been drawn up in many parts of the world. In the early stages, they focused specifically on the condemnation of problems, as was the case of the 1965 manifesto calling for environmental justice. More recent manifestos continue to condemn problems, but also to present alternatives and systematic proposals that seek to establish contacts with the scientific world.

Thus, environmental manifestos are written testimonies of our recent history that document the increasing exploitation of resources, and which outline the problems of the social and environmental crisis, as well as changes in our behaviour and way of thinking, coloured by a set of values formed primarily in the context of protest movements. Manifestos also identify the victims of situations of exploitation and the degradation of nature. Indeed, the last fifty years of manifestos are a period in which neoliberal capitalism has ineluctably gained ground, imposing a model based on obtaining social surplus value and exploiting the territory and natural resources. In this paper, we show that manifestos that focus on the relations between agriculture and the environment allow us to chart the transformation of the Sociedade e Território - Natal. Vol. 29, N. 1, p. 6 - 30.Jan./Jun. de 2017 
territory from the 1970s - when extensive rural and natural areas could still be found - to the present day, and the severe environmental crisis we face.

According to Gerard Jori (2011), manifestos appear at times of rupture and change. This explains why, in addition to condemnations of problems, manifestos may be real statements of aims that identify, shape and bring together the concepts and proposals of the group or people who write them or whom they seek to represent. The current validity of such documents is highlighted in Vandana Shiva's "Manifesto for Earth Democracy" (2006), in which the word manifesto is used to refer to a short, simple text that condemns global problems of industrial agriculture and the expoliation of natural resources, and which calls for agricultural alternatives and new forms of democratic organisation that can help coordinate small-scale agricultural initiatives that respect local ecosystems.

Such messages, comprising demands as well as proposals, are characteristic of manifestos which seek, on the one hand, to promote a different society (Alió 2016) and fight against a situation characterised by a host of serious problems and grievances that are perceived as tragic by those who experience them, and, on the other, to offer a perspective on what might be done to transform the situation into the new reality that is sought.

In this article we'll present 37 documents, forming part of a broader set of 133 manifestos. These years were a period is marked by a wide range of manifestos, ranging from the very complex to the very simple. However, every single one of them sought to express a reaction to an environmental threat, of local, regional or global nature. Among these documents, manifestos related to agricultural topics make up a fourth group in terms of number, after those concerned with the protection of natural areas, cities and urban development, and energy. This somewhat secondary position owes much to the belief that urban and industrial processes constitute the main threat to the environment. New topics, particularly those related to agricultural did not emerge until the start of the current century.

\section{Agriculture and urban societies: the formation of a new environmental culture}

Agrarian social history stresses the importance of access to land ownership; however, many demands for land rights around the world remain unresolved. We need look no further than the current movements of landless farmers or farmworkers in many regions of the world. These have led to very interesting political dynamics as illustrated, for example, by the Movimento dos Trabalhadores Rurais Sem Terra (Landless Workers' Movement) in Brazil. In addition to demands for land rights, many new movements have emerged in the West and open up the panorama of protests to other interests and objectives of groups of people that do 
not form part of the rural environment, but who also feel affected by agricultural problems and socioecological issues. We established two points to facilitate understanding this.

\section{The shift towards a new environmental culture}

Some years ago, Parker Gumucio (1992) argued that the processes of change in environmental culture are slow and involve the replacement of existing cultures, which occupy dominant positions. The emergence, therefore, of sustainability as a potential new culture depended on two factors: one, society had to understand the new socio-environmental challenges (for example, global warming and contamination caused by the bioaccumulation of persistent pollutants) and, two, society had to recognise that the cultural and scientific models then available no longer served to explain what was happening. According to this author, not all cultures were equally ready to understand the environmental crisis that was just becoming evident in the 1990s. For example, the bourgeois environmental culture, predecessor of industrial neo-colonialism which continues to be dominant in many places, does not aid understanding of the problems of the socio-environmental crisis. However, other cultures, which could be described as being smaller or embedded in certain circles have a greater capacity to explain what is happening and to draw up proposals for action. This is the case of popular indigenous cultures that have a great capacity for resistance and even for selfreformulation.

This is not as simple as just replacing one culture with another. According this author come into play in the process of building new environmental cultures. These include the emergence of new paradigms in the reformulation of prevailing scientific models, as well as the development of institutional proposals to identify new paths of action. This would appear to have been the objective of the United Nations when, in 1992, it proposed sustainability as the key to world economic development. Yet, as in any historical process, we should also consider the emergence of other cultures, including those that are completely antagonistic to existing cultures and those that try to adapt themselves to them. In 1992, in a stage of "precrisis", Parker Gumucio described the birth of what he called the postmodern urban environmental culture, lying at the intersection between the glorification of consumption and the demand for better environmental quality.

This overview of the environmental cultures of our era is closely linked to our study, because a significant characteristic of the manifestos discussed here is precisely the sequences of phases they have gone through: from the early days when such texts were rare to the 
present-day when they are much more numerous. This evolution probably reflects the fact that in the initial phases, environmental manifestos were only supported by a small sector of environmental groups and highly specialised members of academia. In contrast, the number of manifestos has increased sharply since the start of the current century, having obtained the support of other population groups and collectives.

While it is not our intention here to examine the issue of whether or not we are now immersed in the new, postmodern environmental culture described by Parker Gumucio. We are interested in reflecting the concept of a contemporary historical process that has seen environmental awareness spread from some specific centres to become a new culture with a very strong and critical environmental agenda.

A key topic in the history of science and sociology is the question of the processes via which ideas are formulated and become accepted. S. Quilley (2009) has studied the influence of Aldo Leopold's concept of Land Ethics, taking as a reference N. Elias's approaches to the history of the assimilation of new cultures and the formation of modern civilisation. Thus, according to Elias, the new culture would have gained ground through the population's gradual yet widespread adoption of new customs that had previously been limited to small groups or collectives, until they were shared by the whole of society.

Like this, in a process whose start date we cannot pinpoint, but which could be anywhere between the end of the nineteenth and the start of the twentieth centuries, various signs of an ecological, as opposed to an economic, approach to the relations between society and nature began to emerge. In this context, Aldo Leopold's Land Ethics became a rational turning point. It facilitated the dissemination of these new ideas to other sectors of the population, beyond that is those of the specialised circles of forestry sciences and the conservation movement. In fact, Aldo Leopold stressed the need to implement a wide range of actions to educate people in the new values of respect for and knowledge of nature. His point of departure was the environmental education of farmers, for whom he wrote a handbook for the farmers in 1939 which was to become the first handbook of best practices for sustainability (Quilley, 2009).

Here, however, we examine a phase after that of Aldo Leopold, one in which the world could no longer turn a blind eye to the environmental crisis. These are times in which the new culture of the need to protect nature has become widespread, and extended well beyond the small circles of scientists and environmentalists. 


\section{AGRICULTURE AND INDUSTRIAL FOOD SYSTEMS IN THE PROCESSES OF FORMING THE NEW ENVIRONMENTAL CULTURE.}

A change in culture is not just a question of changing behaviour; people also need to recognise the importance of new ways of seeing things. Below we discuss, albeit in an introductory fashion, two circumstances that are closely related to agriculture that have helped to consolidate new models of thinking.

\section{Loss of agricultural areas in urban regions}

First, there is the simple question of the loss of agricultural areas, particularly in metropolitan urban fringes, due to processes of urban development and the densification of transport networks. In fact, this is a very common process in the evolution of urban systems. In a study of metropolitan regions, J. Montasell (2009) reported that in the European Union (EU-25) there were 83 metropolitan areas with a minimum of 500,000 inhabitants each. This amounts to almost 130 million inhabitants, approximately $35 \%$ of the European population. The territorial and environmental impact of this is especially worrying if we consider that the basic, survival, ecological footprint of urban inhabitants, that is, the amount of land they require to eat and have sufficient space, is around 3 to 4 hectares per person. Moreover, each inhabitant has an additional footprint of 31.4 hectares for water supply and wastewater treatment. In other words, each person needs around 35 hectares in total, which have to be supplied from the relatively close rural/agricultural area.

The problem becomes even more severe if we consider that the loss of these areas occurred very rapidly in just a few decades. The same author (Monastell, 2009) calculated that, between 1957 and 2000, the amount of urban land in the metropolitan region of Barcelona rose from 11,500 to 83,267 hectares. This expansion mainly took place in areas that had previously been used for agricultural purposes. Much of this dramatic expansion occurred between 1992 and 2000, that is, a period of just eight years, during which there was an increase in the order of 4,571 new urban hectares per year. The situation needs to be considered in the framework of the consolidation of the theory of the urban region, and the global competition of urban systems. Such concepts became the predominant cultural discourse, complemented by that of globalisation, according to which agriculture becomes an objective of a specific sector in large, specialised areas of the planet, which tend to lie far from the major Western urban regions. 
A particularly interesting body of literature has begun to emerge examining this growing tendency to protect agriculture and agricultural land in metropolitan urban fringes. The reasons forwarded for these actions include the wish to safeguard food security in cities, to uphold the ecological balance in urban territories, and to meet growing demands from large segments of the population for a supply of local, quality food.

\section{Industrialisation of agriculture and food}

The second issue is related to food supply, which has become increasingly dependent on the agri-food and phytosanitary industries that are beginning to dominate the social structures and methods of agriculture. This has often been to the detriment of the ecological quality of agricultural systems, resulting in widespread soil contamination and a loss of the biodiversity on which many food systems are sustained. Clearly, it also has an impact on the quality of food products available on the market.

New approaches coincided with the strengthening of the concept of food security, which now extends beyond concerns of quantity to focus on the quality of staple. In Europe, such questions began to emerge at the start of this century with the outbreak of mad cow disease which, along with genetically modified foods and critical episodes of food contamination, created a number of major food security scares. All these episodes involve technological and industrial components related to food production and distribution, which take place at an increasing distance from where food is consumed.

Infante, Aguilera and Gonzalez Molina (2014) have studied the consequences of the progressive industrialisation of agriculture in Spain. They explain that, in addition to the loss of rural ecosystems, exponential increases in automation that have pushed farm labourers out of the sector, and the increasing consumption of animal products, the food distribution sector has grown, a process in which cities have played a leading role. The current food problem is due, in part, they claim, to the tendency for units of sale and distribution to be concentrated in a staggered way throughout the transport and consumption system. Other contributing factors are the sharp increase in the number of catering monopolies and the rise in mid- and longdistance transport, along with enhanced conservation and refrigeration systems, which also reinforce the technological-industrial system of food and agriculture. All of this has an impact on the environment and on health.

City residents constitute a broad segment of the population that are potentially involved in these issues. Indeed, earlier studies report that the introduction of the processes of 
industrial agriculture can help explain the recent development of precautionary strategies among specific sectors of the population. This is particularly true of issues affecting children, as shown by the increasing number of schools in many countries offering organic food (Alió 2013).

\section{AGRICULTURAL MANIFESTOS IN CATALAN CONTEMPORARY DYNAMICS}

As mentioned, the manifestos discussed here form part of a larger set of 133 texts written between the 1970 s and the first 13 years of the current century. This period is, we believe, long enough for us to propose some ideas regarding the way in which they fit into the broader social, political and intellectual context. We follow this with a more detailed analysis of the manifestos.

\section{Chronology}

In a first analysis of these texts (Alió 2012 and 2013; Jori 2011) we discussed marked differences between an initial, very short phase in the 1970s and 1980s, and a second phase after 2000. Between these two main phases, there was a period of several years in which there was a sharp drop in the number of manifestos being written. Thus, we can, more accurately, define three periods (Figure 1). The first coincided with the end of the Franco regime and the years immediately after the dictatorship when protest movements emerged in a climate of newly gained freedoms. This was followed by a period marked by an almost total absence of manifestos, coinciding with the years of political transition from dictatorship to democracy. These were years characterised by a feeling of confidence among much of the population, due to the changes that were soon to be ushered in (Alió 2013; J. Bigues 1991; S. Vilanova 2004). This was followed by a third stage (taking us up to the present day) typified by the re-emergence of social demands and the renewed publication of manifestos. This phase corresponds to that of the current context of widespread of the socio-environmental crisis (Naredo 2000), which has seen the development of new citizen movements.

Although there are far fewer manifestos dedicated to the protection of agriculture than to other topics, they nevertheless adhere to this same pattern. Figure 1 shows the very small number of agricultural manifestos published in the 1970s and in the intermediate period until 2000 , and the fact that most of the manifestos in this category were published after the year 2000 . 
This sequence has various interpretations, but they are all strongly interconnected. From an economic viewpoint, their chronology points to the two main economic cycles experienced by Spain. The first was marked by a technological/industrial monopoly, which was challenged by the environmental movement in particular, as well as by other groups, on the grounds of the resulting commitment to the nuclear industry. And, the second was that of the great growth experienced in real estate, the speculative constructions and the financial capitalism (which had already begun to emerge in the 1970s as we shall see below), and which had a considerable impact on many areas of the territory from the start of the new century.

Figure 1: Chronology of manifestos in Catalonia

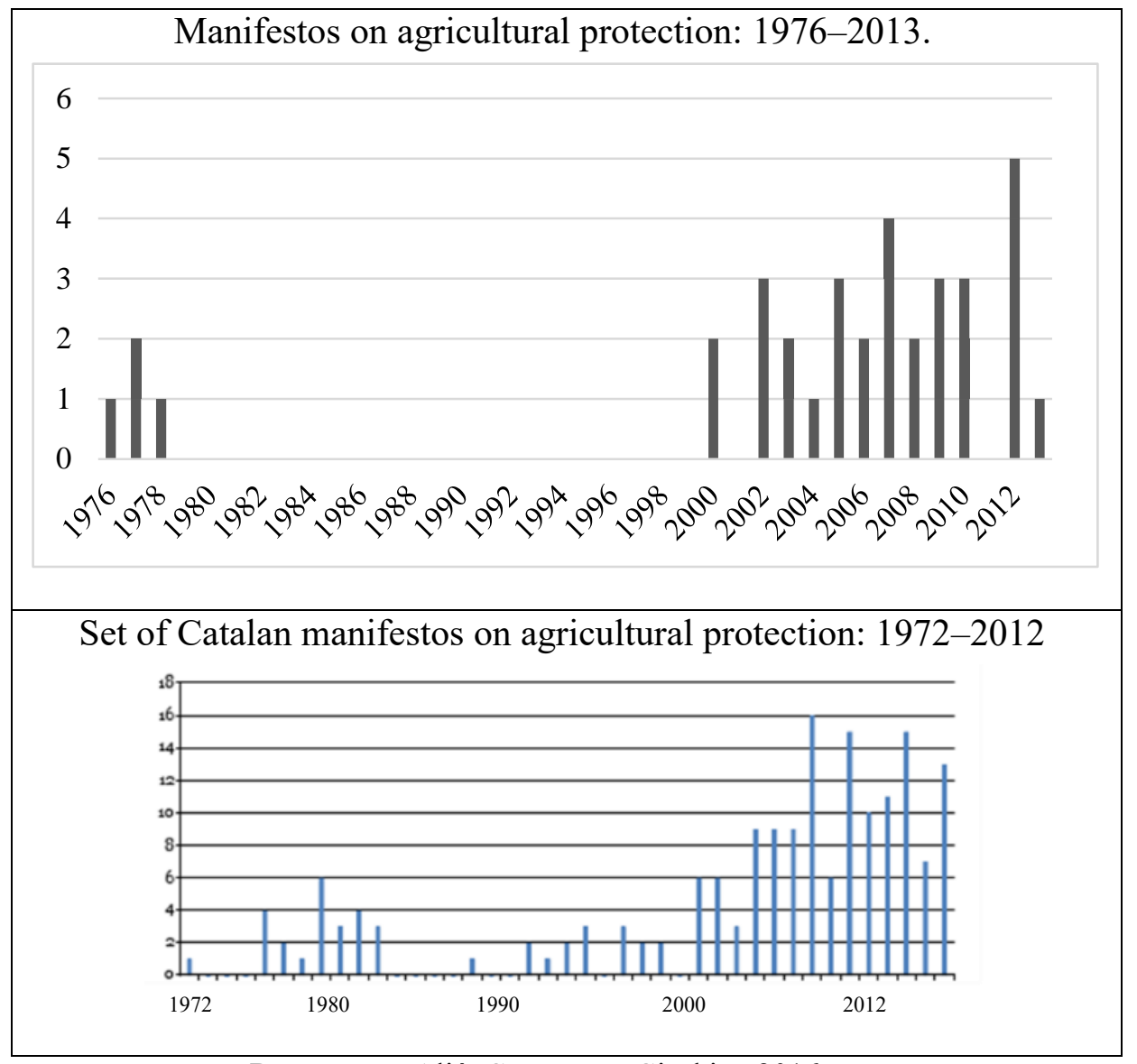

Data source: Alió, Casanovas, Giachino 2016.

This chronology needs to be approached also from a more social perspective, given that during this period major changes occurred in the dissemination of knowledge and with it emerged a new generation of young people who were much better educated. At the beginning of the 1990s, R. Inglehart (1991) described the impact on Western societies of their having entered a period in which the job market was relatively stable and inclusive. This enabled Sociedade e Território - Natal. Vol. 29, N. 1, p. 6 - 30.Jan./Jun. de 2017 
social movements to focus on what he considered "post-materialist" values, including environmentalism, along with solidarity and animal rights, among others. This shift was also linked to the computer revolution and the emergence of new generations that are better prepared professionally and culturally. As a result, social movements acquired a greater capacity to organise themselves and to act. A similar situation can be said to have existed in Catalonia, which despite its specific characteristics, contributes to our understanding of why agricultural manifestos flourished after 2000.

\section{The authors: from early manifestos to new eco-territorial movements}

It would seem that this dissemination of "post-materialist" values and the ecological movement emerged at the same time as the world was faced by increasing problems of environmental degradation and territorial exploitation. In this context, manifestos were an important instrument for two reasons. First, they were the material support for disseminating information about protest campaigns and their objectives beyond the areas inhabited by the population directly affected. Second, the formal characteristics of the manifesto - their emphasis on brevity and clarity - provided those that read them with concepts and arguments that could be readily understood and digested (Alió 2013 and 2016).

With some exceptions, the manifestos were generally co-written by various authors involved in the protest. Our analysis reveals, however, that, as the years passed, some of the characteristics of these authors changed. In particular, there was an increase in texts written by members of citizen pressure groups, as opposed to a predominance of authors from the scientific and environmental associations (Table 1). This table shows the four basic types of author: scientists and professionals, environmentalists, citizen groups and public platforms. In general, there is a fairly even distribution across the four types with public platforms constituting the main authors.

Table 1: Authors of manifestos

\begin{tabular}{|l|c|}
\hline \multicolumn{1}{|c|}{ Author } & Number of manifestos \\
\hline Scientists and professional associations & $9(24.5 \%)$ \\
\hline Environmental associations & $9(24.5 \%)$ \\
\hline Citizen associations and groups & $6(16.0 \%)$ \\
\hline Citizen platforms & $13(35.0 \%)$ \\
\hline TOTAL & 37 \\
\hline
\end{tabular}

Data source: Alió, Casanovas, Giachino 2016. 
During the 1970s, we find authors from the first three groups; yet, it is not until the year 2000 that the citizen platforms emerge as authors of manifestos, representative of a new, more complex type of collaboration and citizen organization. For example, the first manifesto for the protection of Alfacs, in the Ebro Delta (1976), was written by the Scientific Committee of the Col-legi de Doctors $i$ Llicenciats de Catalunya (Catalan Institute of PhDs and Graduates). Only one year later, in 1977, the Societat Naturista Vegetariana (Natural Lifestyle Society) of Barcelona published their manifesto entitled Envers un Procés Constituent Naturista (Towards a Natural Lifestyle). In the same years (1977 and 1978), two new manifestos appeared, promoted by the rural inhabitants and farmers of Gallecs in the area of the Vallès, one of the few remaining agricultural zones in the metropolitan area of Barcelona 5 .

Over the next two decades, agricultural areas and farmers came under ever growing threats, while concerns grew among the population. Perhaps this explains why a new generation of manifestos emerged from 2000 onwards. One of the first of these new texts was written by a platform of residents and groups from municipalities in the lower reaches of the basin of the river La Tordera, which suffered a serious overexploitation of its water resources to the detriment of potential farming. In the same year, another platform comprised a broad set of groups and associations of municipalities published manifestos to protect the rural areas of the Ordal-Montbaig-Montpedrós mountain area in the urban metropolitan fringe of Barcelona $^{6}$, a zone threatened by urban sprawl and speculation. In 2001, a manifesto was published calling for the agrarian spaces protection of the Maresme, lying to the north of the Barcelona conurbation. This was followed in 2003 by new manifestos with the same goals, condemning the process of speculation and the urban development policy in the area.

This effort on the part of citizen groups and associations to coordinate their actions, including writing and disseminating manifestos, has continued without interruption to the present day. Indeed, for several years before the turn of the century, coordinated actions of this kind had very much matured into an organisational strategy for the third sector (Alió and Bru 1992, Alió and Jori 2000 and Alió 2011). As Nogué and Wirbrand (2010) report, such actions seemed to adapt especially well to eco-territorial protests where the focus is on upholding environmental, social and territorial values.

\footnotetext{
${ }^{5}$ Especially notable here was the support offered by geographer Pau Vila in an interview for a local newspaper: "Don't let Gallecs be taken!", he says.

${ }^{6}$ These are three manifestos on the Protection of the Natural Area in Montbaig-Montpedrós-Puig Vicenç. They appear to be the same, although they became increasingly detailed as new members joined the platform.
}

Sociedade e Território - Natal. Vol. 29, N. 1, p. 6 - 30.Jan./Jun. de 2017 
At the same time, the scientific and professional community continued its production of manifestos, producing arguably more sophisticated documents. For example, in 2003, a manifesto was drawn up jointly between professional and academic associations and an agricultural trade union. All of the participants had come together at a meeting held in Manresa, a small city to the north of the metropolitan region.

Five years later, the authorship of manifestos had become an even more complex undertaking. For example, two manifestos published in 2008 showed how the composition of the participating groups of professionals had become increasingly more varied, and how each brought their own perspectives to the table. The first of these was the manifesto supporting the campaign Som el que sembrem (We are what we sow), promoted by a group of food and nutrition professionals who encouraged citizen actions in favour of a law prohibiting the use of genetically modified organisms. The document also highlighted the importance of food for human health and the need to recover traditional agriculture as part of the new organic agricultural movement. It condemned the agricultural model based on the use of synthetic fertilisers and phytosanitary products. Another remarkable feature is that, for the first time in a manifesto, the concept of food sovereignty was used explicitly as a right of local communities to define their own methods of agricultural production, marketing and consumption of foods in a framework of respect for local biodiversity.

The second manifesto, published by a net of environmental associations, supported the campaign Fora els pesticides de les nostres vides (Pesticides out of our lives). This document condemned the use of synthetic chemical substances in agriculture. The text was long and the style was complex, halfway between a formal denunciation and a technical report. It called for the maintenance of agriculture as an essential factor in the conservation of the natural heritage and as a critical part of a model of a quality agricultural system that is environmentally sustainable.

Next, in 2009, the same campaign Som el que Sembrem issued a new version entitled Manifest de Bellpuig (Manifesto of Bellpuig) ${ }^{7}$, in which it reasserted the platform's position in defence of a new agriculture that would safeguard health, farmers, land, biodiversity and the territory, a set of closely related elements considered critical in maintaining the agroenvironmental relationship. A year later in 2010, a manifesto was published by the Xarxa Catalana de Llavors (Catalan Seed Network), an organisation made up of professionals

\footnotetext{
${ }^{7}$ Little town (5.005 inhabitants in 2016) of the rural subsystem in Catalonia. 
concerned with the preservation and cultivation of native seeds. This publication, one again, addressed food sovereignty, agricultural biodiversity, seed banks and small-scale agriculture.

However, agricultural land speculation continued, and in 2012 the last professional manifesto in this series was published ${ }^{8}$. It was written by a committee of the Col.legi d'Arquitectes (Institute of Professional Architects) and condemned plans to construct a large leisure and gambling complex on land belonging to the Parc Agrari del Llobregat, a protected agricultural zone to the south of the Barcelona conurbation. The document called for appropriate and rational planning for the agriculture and environment in this metropolitan zone. In 2013, the last manifesto promoted by platforms was published calling for the protection of the Torre d'en Mornau ${ }^{9}$, a large complex of 90 hectares agricultural buildings in the national park Aiguamolls del Empordà. This manifesto was written by the largest, most varied platform of all those described so far. It was made up from many different members in terms of their specialised field, including agriculture, culture and architecture, and their origin, being constituted by local groups and individuals, as well as activists from Barcelona and abroad.

\section{Main themes in agricultural manifestos}

As discussed, manifestos normally comprise two elements: the demand and the proposal. However, when we focus specifically on agricultural manifestos, other themes and issues emerge closely related to farming and agriculture (Alió 2016).

We can distinguish up to three main issues of agricultural manifestos (Table 2 and Figure 2). The first are those that prioritise the relationship between agriculture and natural ecosystems. This is the largest group, with a total of twenty-two documents. The first and last manifestos in our sample serve as good examples of this type: the manifesto calling for the protection of Alfacs in the Delta del Ebre and that calling for the conservation of the Torre d'en Mornau. The second type of manifesto did not appear until 2004 and is characterised by having a very clear focus on questions related to agriculture, although it also considers some of the interrelations between agriculture and the environment. Two of these interrelations are, in fact, extremely important, to the extent that we could divide this second type of manifesto into two subgroups. One prioritises relationships with places and territories that are basically,

\footnotetext{
${ }^{8}$ After the specific period studied here, a group of scientists and professionals, many from academia, have written another manifesto. Everything indicates that this will not be the last.

${ }^{9} 90$ agricultural hectares with $5.000 \mathrm{~m} 2$ builded. Today is in process to transform in a agroecologic equipment.

Sociedade e Território - Natal. Vol. 29, N. 1, p. 6 - 30.Jan./Jun. de 2017
} 
but not exclusively, urban areas. This subgroup includes eight manifestos, including documents written to denounce the Eurovegas project, to protect the hortes (vegetable gardens) of Lleida and Banyoles, and to protect the agrarian land of the Segarra-Garrigues canal in the agricultural regions of inland Catalonia. In contrast, the second subgroup is smaller - just four manifestos - and the documents were published slightly later, between 2008 and 2010. These manifestos clearly belong to the discourse of the cross-cutting relationships of agroecology, being an obvious manifestation of the interrelations between agriculture, food and health, in line with what Wezel and their team (2009) and Sevilla and Woodgate (2013) consider one of the main currents within these new social movements. Two of these documents were published in 2008 , one on healthy food and the other on pesticide use. The third, published in 2009, was the Bellpuig manifesto and the fourth, published one year later, was the Xarxa de Llavors manifesto (for details, see above).

Table 2: The main themes of agricultural manifestos

\begin{tabular}{|l|c|}
\hline Classification by main relationships & Number \\
\hline Agriculture in natural ecosystems & 22 \\
\hline Mainly on agriculture & 12 \\
\hline Associated with places and regions & 8 \\
\hline Agroecological & 4 \\
\hline Complex interactions & 3 \\
\hline Total & 37 \\
\hline
\end{tabular}

Data source: Alió, Casanovas, Giachino 2016.

Figure 2: Percentage of total manifestos corresponding to each theme $\mathrm{e}^{10}$

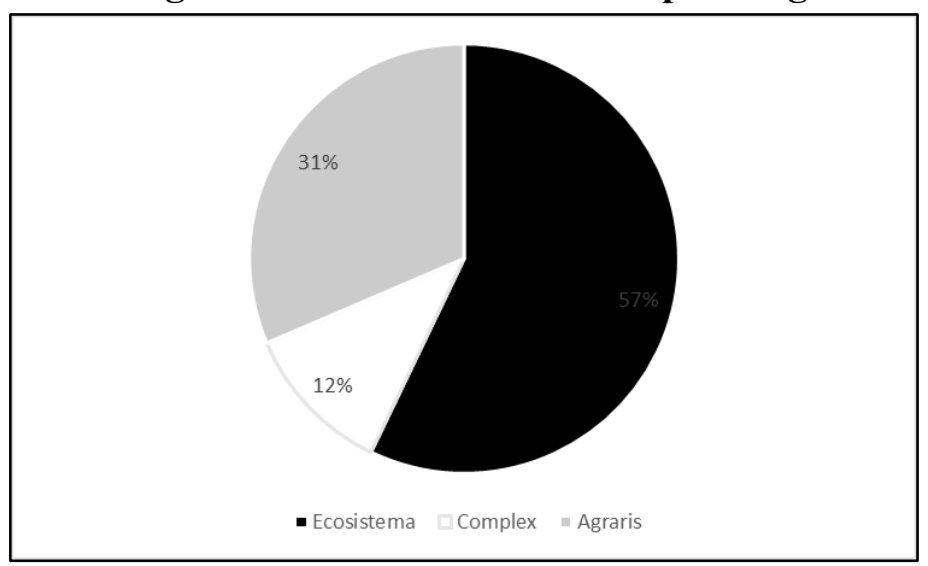

Data source: Alió, Casanovas, Giachino 2016.

\footnotetext{
${ }^{10}$ Excluding the manifesto on urban planning in the Maresme county, which more degree of complexity. This manifesto was not identified until the research for this study had been completed, and we were already in the process of writing this document. However, we return to it later when discussing more specific aspects of these documents.
}

Sociedade e Território - Natal. Vol. 29, N. 1, p. 6 - 30.Jan./Jun. de 2017 
Third, and finally, there is an even smaller group, comprising just three manifestos, which we consider separately because they are of an even greater complexity than those in the other two groups. The first, published by the Societat Naturista Vegetariana (Natural Lifestyle Society) in 1977, addresses the relationships between the food of urban societies and agriculture. Although it examines the situation in Barcelona, it could be referring to almost any city in Western Europe. Its complexity lies in the fact that it opens the door to many other issues, including the environmental quality of cities, urban development, and the need for inhabitants to take an active stance in protecting their environment. It was not until 2007 that the second manifesto in this group appeared, by far the most complex publication up to that date. This manifesto sought to protect the Terres de Ponent. In contrast to the manifesto described above, it addressed the situation of rural areas in inland Catalonia and the problems that appear in these territories when agricultural systems become progressively dominated by the agri-food industry. The third manifesto in this group was published in 2010. It returned to the earlier arguments of the Natural Lifestyle Society, but sought to place them in a more upto-date context. While this group of manifestos is small, they clearly illustrate the range of agricultural problems faced by the rural and urban environment.

To sum up, we have seen that in the period studied here, all the manifestos addressed the interrelationships between agriculture, society and territory. Some stressed the role agriculture plays in ecosystems, others emphasised the many ways agriculture is related to society and how it performs the invaluable function of helping to rebalance urban systems. This connection between agriculture and the specific geographical locations that are the point of focus of the manifestos provides further elements to help us appreciate the scope of these texts. We look at this aspect in more detail below.

\section{MANIFESTOS IN THE TERRITORY}

If we focus on the locations to which the manifestos refer, rather than on the distinct relationships they forge between agriculture and other issues of importance, we see that a large number can be associated directly with a specific place or places. In fact, thirty manifestos, that is, over two thirds of the total, refer specifically to one place. This is not surprising if we consider that many were written in the context of eco-territorial conflicts in which the population clearly identified with the place and expressed a deep commitment to their immediate environment (Nogué and Wilbrand 2010). 
Table 3 shows these locations. Notably, over half of the manifestos, 23 to be exact, refer to urban places, either to metropolitan areas (16 manifestos) or cities (7 manifestos). This would appear to be indicative of growing concerns among urban dwellers for issues related to agriculture, or, at least, among those segments of the population that express greatest interest in social and environmental issues.

\section{Table 3: Location of agricultural protection manifestos}

\begin{tabular}{|l|c|}
\hline Location & Number \\
\hline Barcelona Metropolitan Area & 16 \\
\hline Metropolitan cities & 1 \\
\hline Other cities & 6 \\
\hline Rural areas & 8 \\
\hline Total & 31 \\
\hline
\end{tabular}

Data source: Alió, Casanovas, Giachino 2016.

We examine these locations in greater detail.

\section{Manifestos for the protection of agricultural spaces in urban areas}

In one of the first studies dedicated to these manifestos (Alió 2011), we examined the fact that most of these documents tended to be associated with urban areas. This brings to mind what Daniel Coleman (1994) referred to as the urban environmental paradox: according to which it is the cities and urban areas - that is, the most artificial ecosystems with the largest number of inhabitants and with the greatest environmental impacts - that are most willing to do what they can to reduce these impacts and improve their environmental conditions. This tendency is particularly apparent in our manifestos, particularly in their defence or calls for the reintroduction of certain agricultural land uses, or their attempts to ensure better food conditions for the urban population.

Figure 3 shows the location of these manifestos. We can see a clear concentration in metropolitan neighbourhoods in the south and west of the city of Barcelona. In these areas, with their high population densities, there is a conviction that agricultural zones, vegetable gardens and fruit trees mainly, close to the city are very necessary. This view is especially present in the metropolitan districts of Vallès Occidental and Baix Llobregat, which together house almost 2 million inhabitants, that is, over $20 \%$ of the Catalan population ${ }^{11}$. Since the 1960s, property developers have exerted considerable pressure to build on the agricultural land in these locations, leading to the formation of various platforms whose goal it is to

$117,516,254$ inhabitants in 2015.

Sociedade e Território - Natal. Vol. 29, N. 1, p. 6 - 30.Jan./Jun. de 2017 
protect them. A good example of this is the mentioned mobilization to protect the agricultural areas of Gallecs.

The conflict, however, has continued unabated, culminating in a situation in which the combined effects of urban and industrial growth saw urban land use in Vallès alone increase from 7,349 to 22,000 hectares between 1972 and 2003. This represents a 300 per cent increase in urban areas (Casanovas 2013) in a process that has affected both its former rural areas as well as its cities. Likewise, Sabadell and Terrassa, the two largest cities in Vallès (with over 200,000 inhabitants each), have been affected. Sabadell, with 207,814 inhabitants in 2015, was the first city to act when in 2007 it responded to the demands of various social actors to protect the remaining cropland around the city. Today, this area is an agricultural park of 568 hectares. Five years later, in 2013, Terrassa $(215,214$ inhabitants in 2015) was also the focus of another manifesto, which that differed from the previous one as it was concerned with protecting the community vegetable gardens within the city's limits.

Figure 3: Map of manifestos.

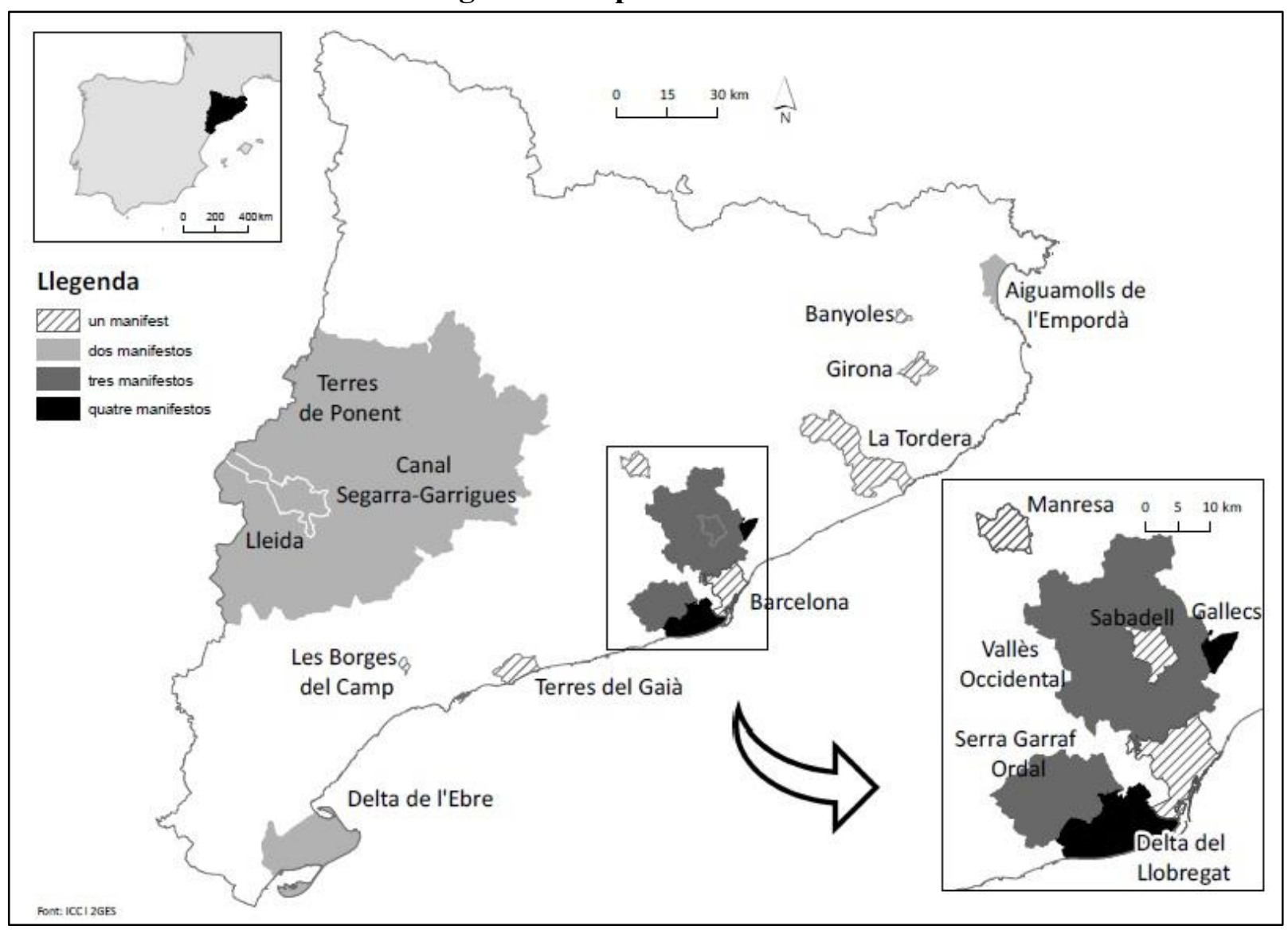

Data source: Alió, Casanovas, Giachino 2016. 
More recently, a similar process has taken place in the new metropolitan area of Tarragona-Reus to the south of Catalonia (c. 500,000 inhabitants). Here, one manifesto has sought to protect the El Freixe area from property developers anxious to urbanise agrarian land.

Figure 3 also highlights other locations, scattered across the territory, some urban, others rural. For example, a number of manifestos can be associated with the capitals of inland territorial subsystems, primarily, medium-sized cities. Two focused on the large city of Lleida (more than 400,000 inhabitants), calling for the conservation of the vegetable gardens. Another focused on Manresa, with a population of 74,655 inhabitants in 2015. This document called for the preservation of the city's historic system for irrigating its vegetable gardens, and supported its residents demands for local food. Yet another was associated with Girona, a city with almost 98,000 inhabitants, and had similar objectives. Other manifestos were linked to smaller settlements. For example, in Banyoles (c. 20,000 inhabitants) also there is a manifesto for the preservation of the vegetable gardens. As we can see, a typical concern captured by the manifestos is the preservation of areas for growing vegetables and fruit trees. However, in some places, demands focused more specifically on preserving areas for non-irrigated agriculture and small horticultural enclaves.

Many authors have discussed this process by which increasing pressure was placed on the countryside and that has been identified as an inherent characteristic of capitalism (Sempere 2005, Monastell 2009, Perxacs 2011 and Carta de la Agricultura Periurbana 2014). Recently, Segrelles (2015) noted that the ubiquity of this phenomenon has forced public bodies to take responsibility for protecting these spaces, precisely because of the pressure brought to bear by citizen groups and farmers' guilds, counting, on occasions, with the support of professional associations and university members.

\section{Urban planning and protection measures}

Table 4 provides a better understanding of the relationship between the citizen movements that led to the drafting of these manifestos and the development of urban planning instruments, which are what eventually guarantee the protection of these agrarian spaces. This table shows the two main legal measures that control nowadays the use of soil and protect the agrarian spaces: the Plans d'Ordenació Urbana Municipal (POUMs) or municipal urban 
plans and, the environmental measures, primarily European Directives and the Catalan Plans ${ }^{12}$.

Table 4: Planning protection tools of the manifestos

\begin{tabular}{|c|c|c|c|c|c|}
\hline & \multirow{2}{*}{ MANIFESTOS } & \multirow{2}{*}{$\begin{array}{c}\text { MUNICIPAL } \\
\text { URBAN } \\
\text { PLANS } \\
\text { (POUMS) } \\
\end{array}$} & \multicolumn{3}{|c|}{$\begin{array}{c}\text { AGRARIAN AND ENVIRONMENTAL } \\
\text { PROTECTION PLANS }\end{array}$} \\
\hline & & & Local & Catalan & European \\
\hline Urban & 23 & \multirow{2}{*}{ All } & \multirow[t]{2}{*}{3} & \multicolumn{2}{|l|}{3} \\
\hline Rural & 8 & & & 3 & 4 \\
\hline
\end{tabular}

Data source: Alió, Casanovas, Giachino 2016.

The first thing to highlight is the fact all the manifestos do have corresponding urban planning instruments. However, this merely serves to confirm that these measures fail to provide adequate protection for the agrarian spaces, as demonstrated by the demands laid out in the manifestos reviewed up to this point. Carceller (2011) explains that the POUMs did not actually begin to focus on protecting agricultural and rural areas until the middle of the first decade of this century. This makes the effects of citizens' demands for more protection of rural areas and the vegetable gardens especially.

In fact, the three Montbaig-Montpedrós manifestos called for such protection via a public consortium that seeks to protect forests and rural areas. Similar demands were made in the manifesto published in Manresa in 2003. Three years later, the local government approved the protection of 150 hectares in the areas called Poal and Viladordis, under irrigation from the small reservoir of l'Agulla - la Sèquia. A similar initiative was taken two years later in Girona, with the approval of a Special Plan for the Hortes of Girona, after citizens demanded the protection of the market gardens of Sta. Eugenia. In the same and following years, similar processes were initiated in Banyoles and Lleida. Another interesting example is provided by El Freixe, on the edges of the urban-industrial conurbation of Tarragona-Reus. Up to 2005, the date of the manifesto in question, this area had managed to preserve a good level of heritage and environmental quality. However, there was a plan to develop part of this zone, where the Catalan Land Institute (INCASOL) had purchased for housing within the framework of a POUM.

A number of municipalities began to promote the so-called Agrarian Parks -agroenvironmental projects to protect the agricultural traditions of their farming areas. The first,

\footnotetext{
${ }^{12}$ The European Habitats Directive and the Plan for Areas of Natural Interest, PEINs for Catalonia. Sociedade e Território - Natal. Vol. 29, N. 1, p. 6 - 30.Jan./Jun. de 2017
} 
and the largest of these (3,348 ha) was that of Baix Llobregat, followed by the parks of Sabadell and Gallecs.

Despite the gradual incorporation of measures to protect agricultural areas, the idea that rural zones can act as urban reserves on the outskirts of cities has yet to be adopted by some urban agents, including government bodies that, on occasions, do not hesitate to set in motion speculative dynamics. Nowhere is this situation more apparent than in the project known as Eurovegas which inspired four manifestos in just one year. These manifestos condemned plans for an 800-hectare leisure and gambling complex to be built within the aforementioned Parc Agrari del Llobregat, one of the few zones in the Barcelona Metropolitan Area that has managed to maintain the agricultural use of the land and that has strong legal protection.

\section{Agriculture in rural areas}

Table 1 and Figure 3 also include the manifestos associated with dry farming in both rural and coastal areas and in lower river valleys as they join the sea. In the latter cases, the manifestos seem to relate directly to the pressures of speculation experienced in economies tied to beach tourism. Two manifestos are concerned with the riverbanks of the Ebre and its Delta; two with the River Gaià; one with the River Tordera; and another with the wetlands of the Empordà ${ }^{13}$. In addition, there are two manifestos associated with inland areas of the Lleida region, which shows that calls for the protection of agricultural lands continue to be made in rural inland areas.

Although this group of manifestos is small, we can extract two interesting messages. The first is the importance of agriculture in natural ecosystems. The safeguarding of this ecological function is a constant, unavoidable demand, and one that appeared in the first of these manifestos. In this framework of environmental and natural approaches, there are a further two aspects that add depth to the text and its messages: the need to transform agricultural practices to ensure they fit the model of sustainability. The second message is that the discourse of conservation of these manifestos is complemented by social demands. Two of these are particularly notable. The first is that agricultural economies must be economically viable and enable farmers to continue their activity and make a satisfactory living. In some manifestos, this is linked to historical demands brought against large landowners and the

\footnotetext{
${ }^{13}$ The first manifesto written in 1976 calling for the protection of the Aiguamolls del Empordà could also be added here. This manifesto was crucial to the first implementation of the legal concept of PEINs in Catalonia.
}

Sociedade e Território - Natal. Vol. 29, N. 1, p. 6 - 30.Jan./Jun. de 2017 
system of intermediaries, whereas in others, it is associated with demands for the implementation of measures to enable young people to access the land. The second social demand is that agriculture and livestock farming should serve as a supply of healthy food to the urban population.

\section{CONCLUSIONS}

To conclude this article, we wish to stress various issues. First, with the passing years, the agents that participate in environmental movements have become increasingly more diverse and numerous. In addition to the historic leaders of these movements, which included environmental groups and certain segments of the academic and professional world, a broad range of associations and groups has also added other voices.

This trend is reflected in an increase both in the number of manifestos from 2000 onwards as well as in the appearance of aspects of a more qualitative nature related to culture and life in the territory. The map of places associated with many of the manifestos clearly reveals the widespread concern of urban inhabitants to preserve agricultural zones on the outskirts of urban areas. This concern has been identified repeatedly in cities of all sizes. In recent years, we have even seen an interest in reintroducing hortes within the urban fabric itself. This desire forms part of a new agro-urban vision firmly entrenched within the framework of a new way of understanding and considering the traditional relations between city and countryside.

And second, this collection of documents reveals is a new vision in which the interest in agriculture is paramount. This is even more evident when we consider that the preservation of agricultural areas also forms part of a more complex view that extends beyond landscapes and land uses to address the role of agriculture, defined in the framework of ecosystem relationships and of human life. Consequently, we wish to highlight the relevance of manifestos that also discuss the changes required in agricultural systems as they move towards the introduction of organic farming, which is of crucial importance to human nutrition and human.

What we are witnessing are a whole series of cultural changes that also form part of the expansion of a new environmental culture. These changes reflect not only a paradigm shift towards more complex views, which take into careful consideration interactions between physical and social factors, but also a recognition of people's needs and capacity to take a proactive stance in relation to future models that are considered advantageous, even when this 
means taking up a position contrary to government objectives. In short, it would very much appear that in the Western world we can confirm the presence of a process of expansion of an environmental culture that extends beyond a contemplative view of nature and assumes that we need to take responsibility for this change. This is perhaps one of the clearest indicators of the current state of the dissemination of Land Ethics, which we discussed at the start of this article.

\section{REFERENCES}

ALIÓ, M. Àngels: De l'acció a la utopia. Els manifestos per a la protecció ecològica del territori i la justícia ambiental a Catalunya. XIV Coloquio Internacional de Geocrítica, Barcelona, 2-7 May, 2016, http://www.ub.edu/geocrit/xiv-coloquio/MAngelsAlio.pdf

ALIÓ, M. Àngels: Els manifestos per a la protecció ambiental com instrument de construcció de la cultura de la sostenibilitat a Catalunya 1972-2012. Papers, Barcelona, Ecoconcern, 2014. 2 vols. 45 pp. and 34 pp.

ALIÓ, M. Àngels - JORI, Gerard: Evolución de las movilizaciones ambientales en Cataluña entre 1970 y 2007. A: J.M. FERIA TORIBIO - A. GARCIA - J. OJEDA (Eds.): Territorios, Sociedades y Políticas. Sevilla, Universidad Pablo Olavide and Asociación de Geógrafos Españoles, 2009, 431-441

ALIÓ, M. Àngels: La paradoxa ambiental urbana: Aproximacions a la formació de la nova cultura ambiental des de la crisi dels residus. En: ALIÓ, M.À i JORI,G (Eds). La reforma ambiental urbana. Visions i propostes al voltant de la sostenibilitat. Barcelona, 2011, 129147. www.ub.edu/cres

ALIO, M. Àngels - BRU, Josepa: L'esquerda ecològica: residus industrials i geografia humana. Documents d'Anàlisi Geogràfica. Bellaterra, 1991-92. 11-32

ALIÓ, M. Àngels: Los manifiestos para la protección ambiental en Catalunya. Buscando aproximaciones a la hipótesis de la resiliencia. Asociación de Geógrafos Españoles, IX

Coloquio de Desarrollo Local, Alacant, 2013

BIGUES, Jordi: El ecologismo en el estado español. Ecología Política. 91-97, 1990

CARCELLER, Xavier: La biodiversitat urbana en l'avaluació ambiental del planejament urbanístic. In: ALIÓ, M.À - JORI,G (Eds). La reforma ambiental urbana: Visions i propostes al voltant de la sostenibilitat. Barcelona, 2011, 79-92. www.ub.edu/cres

CARTA DE LA AGRICULTURA PERIURBANA. Para la preservación, la ordenación, el desarrollo y la gestión de los espacios agrarios periurbanos. Castelldefels, IX- 2014, 12 pp. http://www.agroterritori.org/web2/wp-content/uploads/2014/05/Carta-de-la-Agriculturaperiurbana.pdf 
CASANOVAS, Marc. Actors socials i l'administració en la protecció dels espais agraris periurbans. Els Parcs Agraris de Gallecs i Sabadell. Universitat de Barcelona. Bachelor's degree thesis, 2013. $60 \mathrm{pp}$.

COLEMAN, Daniel A. Ecopolitics: Building a Green Society. Rutgers University Press, 1994. $236 \mathrm{pp}$.

GARCIA, Ernest. El cambio social más allà de los límites al crecimiento: Un nuevo referente para el realismo en la sociologia ecològica. Aposta. Revista de ciencias sociales. 27, Abril 2006. www.apostadigital.com/revistav3/hemeroteca/egarcia.pdf

GIACHINO, Davide. Gli alternative food networks come promotori di cittadinanza attiva e trasformazione del territorio. Torino, Fondazione Giovanni Goria e Fondazione Crt, 2015. http://liste.retelilliput.org/wws/d_read/destovest/Articoli-Tesi/AFN-e ttps://asapcatalunya.files.wordpress.com/2011/03/ccc_manresa.pdfcambiamento_Giachino.pd f.

INFANTE AMATE, Juan; AGUILERA, Eduardo; GONZALEZ MOLINA, Manuel. La gran transformación del sector agroalimentario español. Un análisis desde la perspectiva (19602010). Sociedad Española de Historia Agraria - Documentos de Trabajo. DT-SEHA, 1403, March, 2014 www.seha.info

INGLEHART, Ronald. El cambio cultural en las sociedades industriales avanzadas. Madrid, Centro de Investigaciones Sociológicas - Siglo XXI, 1991, 529 pp.

JORI, Gerard: Manifiestos ecologistas y cultura ambiental. A propósito de un repertorio digital de manifiestos. Ar@cne. Revista Electrónica de Recursos en Internet sobre Geografía y Ciencias Sociales. Barcelona: Universidad de Barcelona, no. 142, 1 January, 2011. www.ub.es/geocrit/aracne/aracne-142.htm

LEOPOLD, Aldo. A Sand County Almanac. Oxford University Press, 1949. 226 pp.

MONTASELL i DORDA, Josep - Raimon RODA i NOYA: Present i futur dels espais agraris en zones periurbanes. Quaderns agraris, 28, September, 2003, 73- 107. (p.98)

MONTASELL i DORDA, Josep: Els espais agraris de la regió metropolitana de Barcelona. Atzavara, 14, January 2009, 73-89.

NAREDO, José Manuel: Ciudades y crisis de civilización. Hábitat- Boletín CF+S, 2000, http://habitat.aq.upm.es/boletin/n15/ajnar.html

NOGUÉ, Joan - Stephanie WILBRAND: Landscape, territory and civil society in Catalonia. Environmental and Planning D: Society and Space. 2010, vol. 28. 638-652

PARKER GUMUCIO, Charles: Modéles culturels et dévélopement durable: une perspective du Tiers-Monde. In: Quel dév'lopement durable pour le Sud? “Alternatives Sud”, L'Harmattan, 1995, 71-100. 250 pp.

PERXACS, Helena: La conciliació entre camp i ciutat: oportunitats per a la sostenibilitat. sostenibilitat. In: ALIÓ, M.À - JORI, G (Eds): La reforma ambiental urbana. Visions i 
propostes al voltant de la sostenibilitat. Barcelona, 2011, 93-110. Available in digital format at: www.ub.edu/cres

QUILLEY, Stephen: The Land Ethic as an Ecological Civilizing Process: Aldo Leopold, Norbert Elias and Environmental Philosophy. Environmental Ethics, 2009, vol 31, 115-134.

SABATER, Francesc et alter: El valor dels espais agraris periurbans: El cas de les Cinc Sènies-Mata-Valldeix de Mataró. Atzavara, 2008, no. 17, 51-60.

SEGRELLES SERRANO, José A.: Agricultura periurbana, parques naturales agrarios y mercados agropecuarios locales: una respuesta territorial y productiva a la subordinación del campo a la ciudad. Scripta Nova. Revista electrónica de Geografía y Ciencias Sociales. Universitat de Barcelona. 1 - II - 2015, Vol. XIX, no. 502. http://www.ub.edu/geocrit/sn/sn502.pdf

SEMPERE, Jordi: La pagesia, gestora o subordinada en el periurbà: semblances i diferències entre la Regió Metropolitana de Barcelona i l'Àrea Urbana de Toulouse (19502000). Doctoral thesis [online]. Barcelona: Universitat Autònoma de Barcelona, 2005.

SEVILLA GUZMAN, Eduardo - WOODGATE, Graham: Agroecology and Sustainable Food Systems. Journal of Sustainable Agriculture Food Systems, 2013. 37: 32-44, http://www.tandfonline.com/loi/wjsa21

SHIVA, Vandana: Manifiesto para una democracia de la tierra: justicia, sostenibilidad y paz. Barcelona, 2006, 232 pp.

VILANOVA, Santiago.: Les arrels de l'ecologisme català. Una experiència personal. Una sola terra. Barcelona, 2004, 19-63.

WEZEL A. - S. BELLON, - T. DOR'E - C. FRANCIS - D. VALLOD: Agroecology as science, a movement and a practice. A review. Agronomy for Sustainable Development, Springer Verlag, 2009, 29 (4), 10.1051/agro/2009004. hal-00886499.

\section{Recebido em Abril de 2017}

Aprovado em Junho de 2017

Publicado em Agosto de 2017 